\title{
Climate Change Implications and Mitigation in a Hyperarid Country: A Case of Namibia
}

\section{9}

\author{
Hupenyu A. Mupambwa, Martha K. Hausiku, \\ Andreas S. Namwoonde, Gadaffi M. Liswaniso, Mayday Haulofu, \\ and Samuel K. Mafwila
}

\section{Contents}

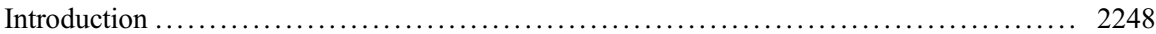

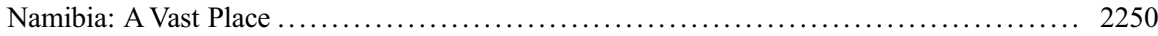

Aerosol Monitoring in Namibia and Its Importance ............................ 2250

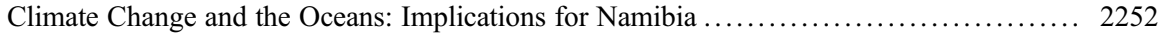

Alternative Water Sources in a Hyperarid Namibia ............................. 2254

Availability of Water in Namibia ....................................... 2254

Seawater Desalination in Namibia ........................................ 2255

Alternative Food Sources under a Changing Climate: Mushrooms .................... 2258

Climate Change Implications on Cultivation of Macrofungi in Namibia .............. 2258

Current and Future Research on Mushrooms in Namibia ........................ 2259

This chapter was previously published non-open access with exclusive rights reserved by the Publisher. It has been changed retrospectively to open access under a CC BY 4.0 license and the copyright holder is "The Author(s)". For further details, please see the license information at the end of the chapter.

H. A. Mupambwa $(\bowtie)$

Desert and Coastal Agriculture Research, Sam Nujoma Marine and Coastal Resources Research Centre (SANUMARC), Sam Nujoma Campus, University of Namibia, Henties Bay, Namibia e-mail: hmupambwa@unam.na

M. K. Hausiku

Mushroom Research, SANUMARC, Sam Nujoma Campus, University of Namibia, Henties Bay, Namibia

e-mail: mkhausiku@unam.na

A. S. Namwoonde

Renewable Energy Research, SANUMARC, Sam Nujoma Campus, University of Namibia, Henties Bay, Namibia

e-mail: anamwoonde@unam.na

G. M. Liswaniso

Mariculture Research, SANUMARC, Sam Nujoma Campus, University of Namibia, Henties Bay, Namibia

e-mail: gliswaniso@unam.na 
Organic Agriculture and Its Potential Under a Changing Climate $\ldots \ldots \ldots \ldots \ldots \ldots \ldots \ldots . \ldots \ldots 1$

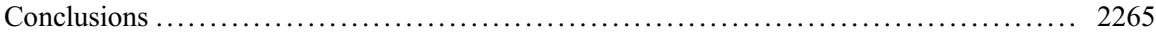

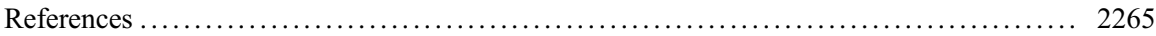

\section{Abstract}

Namibia is the most arid country in sub-Saharan Africa characterized by the existence of two deserts, the Namib and the Kalahari. However, though being arid, agriculture still plays a critical role in Namibia's economy, which includes both crop and animal production. Furthermore, the country is endowed with vast marine resources, with its marine waters being equivalent to two-thirds of Namibia's terrestrial environment. In the face of climate change and a growing population, there is a need for Namibia to continue with its climate smart efforts which is critical in shifting the country from its current dependency on imports thus increasing the country's food self-sufficiency. This chapter highlights the threats posed by climate change, both on land and the marine environment of the country, which has potential negative impacts on the economy. Current research being undertaken in Namibia on ocean acidification, sea water harvesting, climate smart agriculture, and atmospheric science, is also highlighted in this chapter. The information presented in this chapter will be critical in guiding climate change mitigation policies in hyperarid African countries, thus reducing the burden caused by the global change in climate. Aspects on the direction of future research on climate adaptation with a holistic and multidisciplinary approach are also proposed.

\section{Keywords}

Climate smart agriculture $\cdot$ Aerosols $\cdot$ Shellfish $\cdot$ Marine environment $\cdot$ Clean energy $\cdot$ Seawater desalination

\section{Introduction}

Namibia is a very unique country within Southern Africa, being the most arid country in this region characterized by the existence of two deserts, namely the Namib and the Kalahari deserts. On average, Namibia receives $270 \mathrm{~mm}$ of

M. Haulofu

Water Quality Research, SANUMARC, Sam Nujoma Campus, University of Namibia, Henties Bay, Namibia

e-mail: mthomas@unam.na

\section{S. K. Mafwila}

Oceanography Research, SANUMARC, Sam Nujoma Campus, University of Namibia, Henties Bay, Namibia

Department of Fisheries and Aquatic Science, Sam Nujoma Campus, University of Namibia, Henties Bay, Namibia

e-mail: smafwila@unam.na 
rainfall annually, with a wide variation of between $20 \mathrm{~mm}$ and $700 \mathrm{~mm}$ from the western to the eastern parts of the country, with only $5 \%$ of the country receiving more than $500 \mathrm{~mm}$ of rain annually (Sweet and Burke 2006). Within this hyperarid environment, only $1 \%$ of the total surface of the country has medium to high potential for rain-fed crop production. Interestingly, agriculture plays a critical role in the formal and informal economy of Namibia, supporting up to $70 \%$ of the population, with $90 \%$ of this agriculture being livestock based (MAWF 2015). Due to its hyperaridity, Namibia imports most of its food crop requirements from other countries. However, with the advent of climate change which threatens Africa's food production potential, hyperarid and food (especially grain and vegetable crops) importing countries like Namibia will require intensive research on how to mitigate against the threats paused by climate change.

Namibia has achieved some key milestones towards its response to climate change. Firstly, by being party to the United Nations Framework Convention on Climate Change (UNFCC), which meant it must institute policies and measures, informed by science, that reduce the changes on environment and humanity due to climate change (Mapaure 2011). In response to this, Namibia established the Namibian Climate Change Committee (NCCC) in 2001, to advice and make recommendations to government on issues of climate change. In 2011, Namibia developed the National Climate Change Policy (NCCP) which "outlines a coherent, transparent and inclusive framework on climate risk management in accordance with Namibia's national development agenda, legal framework, and in recognition of environmental constraints and vulnerability." (Lubinda 2015). In 2014, the country developed the National Climate Change Strategy and Action Plan for 2013-2020 which lays out guiding principles responsive to climate change that are effective, efficient, and practical (Lubinda 2015).

According to Mapaure (2011), Namibia has identified seven sectors where it is most vulnerable to climate change, and these include water resources; marine resources; agriculture; biodiversity and ecosystems; coastal zones and systems; and health and energy. Within the terrestrial agriculture environment, Namibia is most likely to experience more extreme weather patterns such as flooding and drought conditions under the changing climate. Furthermore, within the marine environment, it is predicted that the increase in northerly or easterly winds could result in suppressed upwelling in the nutrient-rich Benguela system, thus causing the accumulation of oxygen-poor water near the seabed and consequently suffocating marine life (Reid et al. 2008). Therefore, future changes in the distribution and intensity of winds under the changing climate have potential to negatively influence the fisheries sector of Namibia. Against this background, this chapter seeks to highlight some aspects critical for research on climate change in Namibia, while highlighting the current research being undertaken in Namibia at addressing climate change. This chapter focuses more on the coastal environment of Namibia, where climate change research on both terrestrial and marine environments is being championed at the Sam Nujoma Marine and Coastal Resources Research Center. 


\section{Namibia: A Vast Place}

Namibia is located in the southwestern part of Africa between the latitudes of $17.5^{\circ}$ and $29^{\circ}$ South, occupying a total land area of about $824,000 \mathrm{~km}^{2}$, with approximately $526,000 \mathrm{~km}^{2}$ of ocean extending 200 nautical miles into the Atlantic Ocean (https://www.unicef.org/namibia). The country has a population of about 2.448 million people, making it one of the least populated country in the world. The country is characterized by a large coastal area, which covers the entire western border of the country with a length of about $1572 \mathrm{~km}$. In Namibia, the cold Benguela Current has a moderating effect on regional weather patterns which are quite pronounced in the Namib desert, where it creates some unique climatic conditions. Just like most African countries, the contribution of Namibia to global atmospheric pollution responsible for climate change is very limited, though the effects of climate change will be quite pronounced. With Namibia's climate being already variable, climate change is expected to worsen this variability and amplify its adverse impacts (MET 2011). Therefore, with climate change, the focus for Namibia is more on mitigating its effects, which should be the focus of much research, as opposed to focusing on reducing greenhouse gas emissions as the country is not a serious contributor to this aspect.

\section{Aerosol Monitoring in Namibia and Its Importance}

Climate change poses great danger to the livelihoods of many people in Africa and Namibia is not spared from this phenomenon. The country recently experienced the worst drought in decades, that peaked from 2018 to 2019, with some areas receiving none to sporadic precipitation accompanied with floods. Since climate change is driven by several factors, many of these factors are a product of interactions in the earth's atmosphere. Due to these atmospheric interactions, it is important to do longterm baseline aerosol measurement in areas predicted to suffer most from effects of climate change. Though Namibia, like most African countries, does not contribute much to atmospheric pollution, aerosols from global pollution which include black carbon (soot), sulfate, nitrate, ammonium, organic carbon, elemental carbon, and mineral elements can play a critical role in Namibia's climate. Aerosols are suspended particles in the atmosphere, their sizes range from fine (particle diameter $<1 \mu \mathrm{m}$ ) to coarse (particle diameter $>1 \mu \mathrm{m}$ ). Aerosols play several roles of climatic importance as they influence the amount of precipitation by acting as condensation nuclei for cloud formation, while others depending on their nature may scatter and absorb solar radiation thus affecting radiative forcing (Heintzenberg 1985). Aerosol radiative forcing is defined as the effect of aerosols on the radiative fluxes at the top of the atmosphere and at the surface and on the absorption of radiation within the atmosphere (Chung et al. 2005).

The western coast of southern Africa, where Namibia is central, experiences persistent and extended highly reflective clouds mainly stratocumulus and high loads of light-absorbing aerosols from various sources (Formenti et al. 2018). 
However, the mechanisms by which the reflective clouds and light-absorbing aerosols interact to influence the regional radiative budget is largely unknown (Formenti et al. 2018). In other words, the function of aerosols and cloud processes on climate models is still unclear. Due to the importance of different aerosols on regional climate, a ground-based aerosol monitoring station was established in Namibia known as the Henties Bay Aerosol Observatory (HBAO) in 2011 under the University of Namibia at their coastal campus (Sam Nujoma Campus) in collaboration with the Laboratoire Interuniversitaire des Systèmes Atmosphériques (LISA), CNRS/ Universities of Paris Est-Créteil and Paris Diderot, France, and the Climatology Research Group of the North West University (NWU), Potchefstroom, South Africa. This research station focuses on monitoring various parameters influenced by the aerosols. The data generated will form part of the atmospheric baseline studies in Namibia and the southern Africa region, which is important in filling the wide gap in climate change modelling in the region.

The contribution of greenhouse gases on climate change is well investigated, but due to the complex nature of aerosols, their contribution to climate still remains an area of interest to many scientists. As an arid country, Namibia's atmospheric precipitation could easily be affected by the nature of aerosols. If the amount of hydrophobic aerosols increases in Namibia, this could result in reduced rainfall and changes in the fog patterns in the country, which will negatively affect productivity of this arid but unique ecosystem.

In Namibia, the $\mathrm{HBAO}$ is monitoring the various properties of aerosols like those originating from the ocean (which generates microscopic salt particles by evaporation of water from sea-spray), wind-blown dust from the surrounding desert areas, dust from the various salt pans and aerosols generated by veld-fires, and smoke from ships using the Walvis Bay port. Aerosols from each of these sources will have a different composition, and different characteristics such as size, light's absorption capacity, and reflectivity.

In a 3-year study at the HBAO, measurement of mass concentration of equivalent black carbon (eBC, which is a light-absorbing aerosol from biomass burning), it was noted that these aerosols have seasonal shifts that coincide with fire seasons in southern Africa (Formenti et al. 2018), a clear indication that regional sources have contributed to the observations. In addition to these long-term measurements at the HBAO station, an intensive field campaign named the Aerosol Radiation and Clouds in southern Africa (AEROCLO-sA) project using ground-based equipment and a SAFIRE F20 research airplane was conducted in August to September 2017. The results from AEROCLO-sA field campaign are summarized by Formenti et al. (2019). Even though the sources of aerosols in Namibia are less studied, local and subcontinental sources may contribute to the observed measurements since finer aerosols are transported over a long distance. The southwestern African areas experience persistent stratocumulus cloud deck, which increases the total of outgoing radiation, resulting in a generally cooler atmosphere. Increased amount of $\mathrm{eBC}$ will therefore result in warmer atmosphere and may affect cloud formation in the region.

With the projection of increased emission in the world, Namibia is in a region that is predicted to experience rising temperatures and it is expected that a large portion 
of the country will see lowered rainfall with increased number of dry days consequently affecting agricultural productivity negatively. In addition, in desert and coastal areas the rate of fog production may be impacted resulting in less water for plants and animals in these areas. The overall effects of aerosols on climate can be complicated to predict, it is only a long-term observation that can assist in modeling and predicting the climate change regionally and globally.

\section{Climate Change and the Oceans: Implications for Namibia}

Rising atmospheric carbon dioxide $\left(\mathrm{CO}_{2}\right)$ concentrations became evident after the industrial revolution in the $1800 \mathrm{~s}$ as a result of increased anthropogenic activities such as combustion of fossil fuels, agriculture, iron and steel production, municipal solid waste combustion, cement manufacturing, deforestation, and other activities that contribute to emissions of greenhouse gases. The industrial production of $\mathrm{CO}_{2}$ since the $1800 \mathrm{~s}$ has increased the atmospheric $\mathrm{CO}_{2}$ concentration from 280 parts per million (ppm) to $396 \mathrm{ppm}$, and continued increases are predicted to reach $800 \mathrm{ppm}$ by the year 2100 (Branch et al. 2013).

The current atmospheric $\mathrm{CO}_{2}$ concentration is rising at an increased annual rate of $0.5 \%$, that is 100 times faster than any change during the past 650,000 years. The global oceans absorb $25 \%$ of the $\mathrm{CO}_{2}$ released into the atmosphere, from the various listed human activities. The increased absorption of $\mathrm{CO}_{2}$ by the oceans has caused changes in the oceanic chemistry where the concentration of dissolved $\mathrm{CO}_{2}$ has been increasing and consequently resulting in ocean $\mathrm{pH}$ decrease. This reduction in $\mathrm{pH}$, as seawater becomes more acidic, is predicted to decline from approximately 8.2 during the preindustrial era to 7.8 in the $2100 \mathrm{~s}$ (Wei et al. 2014).

When $\mathrm{CO}_{2}$ is absorbed by seawater, a series of chemical reactions occur resulting in the increased concentration of hydrogen ions which causes the seawater to become more acidic and causes carbonate ions to be relatively less abundant. The solubility and distribution of $\mathrm{CO}_{2}$ in the oceans highly depends on climatic conditions and other physical (e.g., water column mixing, temperature), chemical (e.g., carbonate chemistry), and biological (biological productivity) aspects. Assimilation of $\mathrm{CO}_{2}$ into the ocean occurs via the ocean surface to air interface, where $\mathrm{CO}_{2}(\mathrm{aq})$ will react with surface seawater to form a weak carbonic acid $\left(\mathrm{H}_{2} \mathrm{CO}_{3}\right)$ that quickly dissociates into hydrogen ions $\left(\mathrm{H}^{+}\right)$and bicarbonate $\left(\mathrm{HCO}_{3}{ }^{-}\right)$ions, as indicated in the Eqs. (1) and (2) (Doney 2006).

$$
\mathrm{CO}_{2}+\mathrm{H}_{2} \mathrm{O} \leftrightarrow \mathrm{H}_{2} \mathrm{CO}_{3} \leftrightarrow \mathrm{HCO}_{3}^{-}+\mathrm{H}^{+}
$$

Some of the free hydrogen ions $\left(\mathrm{H}^{+}\right)$combine with free carbonate $\left(\mathrm{CO}_{3}{ }^{2-}\right)$ ions normally found in seawater to form more bicarbonate $\left(\mathrm{HCO}_{3}{ }^{-}\right)$.

$$
\mathrm{H}^{+}+\mathrm{CO}_{3}^{2-} \leftrightarrow \mathrm{HCO}_{3}^{-}
$$


This chemical reaction uses up important ocean carbonate $\left(\mathrm{CO}_{3}{ }^{2-}\right)$ molecules needed by some organisms, such as mussels and oysters, to form shells. In addition, the increased acidity of the ocean, caused by the free hydrogen ions $\left(\mathrm{H}^{+}\right)$, causes shells to deteriorate, become thin and frail. Shells in marine organisms are formed by taking up carbonate and calcium in seawater to form calcium carbonate, or the tough cement-like layer we know as a shell, as illustrated in Eq. (3).

$$
\mathrm{CO}_{3}{ }^{2-}+\mathrm{Ca}_{2}{ }^{+} \leftrightarrow \mathrm{CaCO}_{3}
$$

Ocean acidification currently holds the world's attention due to the predicted adverse effects it poses on the marine ecosystems. Monitoring for ocean acidification is crucial in that it allows for forecasting future trends.

Ocean acidification is expected to impact marine species at varying degrees. While microalgae like dinoflagellates and diatoms may benefit from higher $\mathrm{CO}_{2}$ conditions in the ocean, it has dramatic effects on calcifying species, such as oysters, clams, sea urchins, corals, and calcareous plankton. Increased sequestering of atmospheric $\mathrm{CO}_{2}$ in the ocean would result in a lowering of the oceanic carbonate equilibrium. Carbonate ions are important building blocks for structures such as seashells and coral skeletons. Calcifying organisms such as corals are important in the ecosystem as they provide habitat and shelter to various marine organisms and their demise would endanger survival of most of those housed species. There are also other calcifiers that are vital food sources for most marine organisms. Since the calcification of seashells and coral reefs depends on the saturation of the carbonate mineral known as aragonite, it has been suggested that increasing atmospheric $\mathrm{CO}_{2}$ could result in a decrease in the aragonite saturation state in the ocean by $30 \%$ (Takeo et al. 2012).

Namibia has a coastline that is largely uninhabited, unpolluted, and highly productive waters due to upwelling of the Benguela system. Upwelling systems are naturally acidic due to vertical movement of $\mathrm{CO}_{2}$-rich deep waters to the surface and the acidity is increasing due to increased anthropogenic carbon dioxide that is being absorbed by the ocean. These upwelling systems are expected to undergo major changes in the near future due to steadily increasing atmospheric $\mathrm{CO}_{2}$ and the resultant consequences on the ecosystem and fisheries are unknown. Mariculture in Namibia is reliant on shellfish culture with oyster farming being the most established activity, producing both the Pacific and Eastern oyster. Studies have shown how vulnerable mollusks are to acidification but there is still limited data on its impacts in Namibian waters (Waldron et al. 2009). Further research on the effects of ocean acidification on shellfish is being undertaken at the Sam Nujoma Marine and Coastal Resources Research Center, which promises better understanding of this phenomenon on marine life.

The Pacific oysters are farmed in Swakopmund, Walvis Bay, and Lüderitz (now known as !NamiłNûs). This industry is already under threat from the harmful algal blooms (HABs) that frequently occur along the Namibian coastline attributed by high plankton biomass decay that ultimately leads to anoxic events and in some cases eruptions of hydrogen sulfide from the seabed that led to $80 \%$ mortality of 
marine shellfish farmed in Namibia (Anderson et al. 2004). In 2008, sulfur eruptions impacted Walvis Bay marine shellfish farms leading to closure of some farms and relocation of other farms to Lüderitz (OLRAC 2009). With the Namibian marine industry already being influenced by the HAB, ocean acidification of the Southern Atlantic poses a far much greater threat to this industry.

Villafaňe et al. (2015) indicated that the predicated ocean acidification conditions, with increased nutrient and solar radiation could lead to the reshaping of the phytoplankton community, where it would have phytoplankton communities dominated by large diatoms with high growth rates and therefore marine phytoplankton could bloom more efficiently under future acidified conditions than the current conditions. Similarly, when conditions favor phytoplankton, it also infers good conditions for growing seaweed. This would also suggest that the Namibian mariculture industry would lose high-income businesses from oyster culture, loss of employment, and subsequently reduced contribution to the country's GDP. Most businesses would have to shift into seaweed culturing as this will utilize the abundant nutrients, solar radiation, and $\mathrm{CO}_{2}$ in the Benguela upwelling system. Therefore, research that already looks at macro-algae culture for extraction of highly priced phytochemicals is important in Namibia.

Previous research has found out that influxes of iron from terrestrial origin into the ocean led to increased bloom activity in primary productivity (Pollard et al. 2009). Research that involves fertilizing certain oceanic regions with iron, as it is mostly a limiting nutrient, to enhance the sequestering of carbon onto the ocean floor can be critical in mitigating against increased $\mathrm{CO}_{2}$ concentration in the ocean. The resulting blooms would counteract the growing concern of dissolved $\mathrm{CO}_{2}$ and produce organic carbon that would sink to the ocean floor. Norton (2011) suggested the addition of powdered limestone to the ocean in order to react with the dissolved $\mathrm{CO}_{2}$ as another potential mitigation to ocean acidification. As the limestone reacts with the $\mathrm{CO}_{2}$ this will form bicarbonate which would in turn neutralize the acidic conditions of the ocean. These counter action would make calcium carbonate more available in seawater and readily available to calcifying organisms to build their shells. The process of increased calcium carbonate would increase the buffering capacity of the ocean and limit the sequestration of $\mathrm{CO}_{2}$ by the oceans. However, though these researched measures are theoretically feasible, their practicality still requires lot of practical field-based research.

\section{Alternative Water Sources in a Hyperarid Namibia}

\section{Availability of Water in Namibia}

Due to pressures from climate change, global water resources have become vulnerable and scarce, and Namibia is not spared from this phenomenon. Water is a significant resource to human life, the environment and for development, but it is finite. Scientific consensus is that climate change will have a pervasive influence on the future demand, supply, and quality of fresh water resources in Namibia, and 
would add pressure to already stressed water resources and coastal environments (Lahnsteiner and Lempert 2007). Namibia frequently receives below average and highly variable rainfall with high temperatures that result in very high evaporation rates of between 2660 and $3800 \mathrm{~mm}$ per year, which makes Namibia one of the driest in sub-Saharan Africa (FAO 2005). More specifically, the central Namib Desert consists of a flat, gently sloping plain with few topographic features. The steady gradients affect rainfall, temperature, and wind patterns developing between the coast and the interior. The annual mean rainfall along the coast between Swakopmund and Henties Bay is less than $15 \mathrm{~mm}$ per annum, with coastal wind speeds averaging approximately $3 \mathrm{~m} / \mathrm{s}$ in a south westerly direction (Pryor et al. 2009). Likewise, due to climate change, the occurrence of droughts has become more frequent and requires appropriate water management to ensure continued social and economic development of the country (COW 2019). Due to extremely poor rainfalls, the recent drought of the 2018/2019 rainfall season resulted in huge economic loses to the Namibian farmers as livestock and crops died due to lack of water.

The rainfall received accounts for only $2 \%$ and $1 \%$ surface runoff and groundwater recharge, respectively, while $97 \%$ is lost through high evaporation rates in Namibia (Christelis and Struckmeier 2011). The difference between national and regional averages reveals the growing need to seek and implement alternative water supply strategies, in order to secure adequate fresh water and cater for future demand in Namibia under a changing climate. Namibia relies heavily on underground water (aquifers) for the supply of fresh water, which are recharged not only by the rainfall from catchment areas within the country but also from neighboring countries. With such heavy reliance on underground water, particularly in the North Central Regions, the water is at times unsuitable for human and animal consumption due to high salinity (Wilhelm 2012). Climate change is expected to exacerbate this reliance on aquifers for fresh water due to limited recharging of underground water sources. Changes in rainfall and runoff further indicate that underground water recharge may suffer a reduction of $30-70 \%$ across Namibia. In order to adapt to the reduction in freshwater resources, other arid countries including Namibia have begun sea water desalination as a feasible source of fresh water. The reliance is expected to grow as a result of population growth and migration to coastal cities which do not have adequate freshwater resources. In Namibia, the coastal population's overdependence on aquifers constitutes its vulnerability to climate change. However, the vast coastal area of Namibia is also characterized by cool yet sunny environments, rough seas, and very windy areas, all which can be potential energy sources for powering the energy demanding and costly desalination process. Desalination would be a strategic alternative to ensure long-term freshwater supplies, more so when using renewable, clean energy sources for desalination.

\section{Seawater Desalination in Namibia}

On earth, about $70 \%$ of the area is covered by water which is mainly seawater, with only about $1 \%$ of the freshwater being available for human consumption and for 
agricultural purposes in the world's rivers, lakes, and aquifers (Darre and Toor 2018). The scarcity of fresh water resources and the need for additional fresh water supplies are critical in many arid regions of the world (Michou 2017). Worthy to note are the countries in the Arabian Gulf, which are located in an arid area with limited water resources. The region has the lowest availability of renewable water resources per capita in the world. To curb this shortage, the gulf countries invested in seawater desalination technologies that would ensure an adequate supply of freshwater for industries and the more than 300 million inhabitants. To date, the largest market for water desalination in the world is found in the Arabic Gulf (Ramadan 2015).

Even though it offers a sustainable solution to water woes, desalination is energy intensive and comes with environmental consequences. About $0.4 \%$ of the world's electricity consumption is taken up by desalination plants, with global emissions due to nonrenewable energy use in desalination, predicted to reach 400 million carbon equivalents per year. The carbon footprint for reverse osmosis (RO) desalination has been calculated to be between 0.4 and $6.7 \mathrm{~kg} \mathrm{CO} \mathrm{CO}_{2} \mathrm{eq} / \mathrm{m}^{3}$. This means that desalinating 1000 cubic meters of seawater could potentially release as much as 6.7 tons of $\mathrm{CO}_{2}$ (Tal 2018), hence efforts to produce freshwater should not forgo environmental safety. Desalination technologies must be enhanced to become cleaner and more efficient (Compain 2012).

Desalination needs are mainly in dry countries that receive high-intensity solar radiation, hence it makes sense in Namibia to exploit solar power for desalination. Namibia is a country which is abundantly rich in solar energy, as it receives on average of 300 days of sunshine per year, with very few cloudy days. Harnessing this energy from the sun would make it possible to supply the power needed to run desalination plants. The available solar energy makes research and development in solar desalination promising for Namibia. Although at present, renewable resources in Namibia play a very small role in the energy sector, there is potential for renewables to scale up in providing for non-electricity energy sectors. Other alternative and cost-effective sources of renewable energy can also be used for desalination. Renewable energy sources such as wind can be used to generate electricity for use in desalination plants as an alternative to for thermal electric plants. The above alternatives are already being explored in the east coast of Egypt where water resources are limited.

In Namibia, the first desalination plant belonging to Orano Mining Namibia was commissioned in 2010. The desalination plant was originally built to supply water to the Trekkopje Mine near Arandis but has now become part of the potable water delivery system belonging to Namibia's water utility, NamWater. The addition of desalinated water has allowed NamWater to keep meeting the Central Namib's water demand as it provides about $75 \%$ of the overall drinking water to the coastal town of Swakopmund, as well as the nearby uranium mines and other industries (Petrick and Müller 2019). Furthermore, communities of Akutsima and Amarika in the Omusati Region of Namibia benefited from small-scale solar powered desalination plants under the CuveWaters project. These plants aimed to supply the local population with safe drinking water by desalinating saline underground water. This was seen as 
a sustainable way of supplying safe drinking water to the local community, who for years consumed unsafe and salty water.

In an effort to reduce the carbon footprint of desalination, the University of Namibia piloted a $100 \%$ solar powered desalination plant that uses reverse osmosis technology. The pilot desalination plant is evaluating the feasibility of using renewable solar energy for seawater desalination in Namibia's coast. This pilot research project generates approximately $2300 \mathrm{~L}$ of fresh water per hour, which can be very sustainable for supplying water to local communities. Preliminary results of an assessment to determine the mineral composition and grade class of the desalinated water produced at the University of Namibia (UNAM) are presented in Table 1, which point to the suitability of this water for drinking and irrigation according to National and WHO standards.

With this research solar powered plant, the University of Namibia seeks to evaluate various scenarios which include:

- The short- and long-term suitability of solar power in water desalination in the Namibian coast.

- The potential of using this clean energy produced fresh water in desert greening and food production.

- The potential of using desalinated water in enhancing Namibia's contribution to carbon sequestration by using the water to irrigate high carbon fixing trees.

- The potential of accruing carbon credits using various indigenous and exotic tree species irrigated using desalinated water in Namibia.

Table 1 Preliminary results on the mineral composition and grade class of UNAM desalinated seawater

\begin{tabular}{|c|c|c|c|c|c|c|}
\hline Physical constituents & UNAM & $\begin{array}{l}\text { National } \\
\text { limits }\end{array}$ & $\begin{array}{l}\text { WHO } \\
\text { limits }\end{array}$ & Units & Grade & Classification \\
\hline $\mathrm{pH}$ & 5.9 & $6-8.5$ & $6.5-8.5$ & & $\mathrm{~B}$ & Good \\
\hline Turbidity & 0.3 & $<0.3$ & $<4$ & (NTU) & $\mathrm{A}$ & Excellent \\
\hline Conductivity & 45.2 & $<80$ & $\mathrm{a}$ & $\begin{array}{l}(\mathrm{mS} / \\
\mathrm{m})\end{array}$ & A & Excellent \\
\hline $\begin{array}{l}\text { Total hardness as } \\
\mathrm{CaCO}_{3}(\mathrm{mg} / \mathrm{L})\end{array}$ & 7 & $<400$ & $\mathrm{a}$ & $\mathrm{mg} / \mathrm{L}$ & $\mathrm{A}$ & Excellent \\
\hline \multicolumn{7}{|l|}{ Mineral constituents } \\
\hline Sodium as $\mathrm{Na}(\mathrm{mg} / \mathrm{L})$ & 55 & $<100$ & 200 & $\mathrm{mg} / \mathrm{L}$ & A & Excellent \\
\hline Potassium as $\mathrm{K}$ & 3 & $<25$ & a & $\mathrm{mg} / \mathrm{L}$ & $\mathrm{A}$ & Excellent \\
\hline Nitrate as N (mg/L) & $<0.5$ & $<6$ & $<50$ & $\mathrm{mg} / \mathrm{L}$ & A & Excellent \\
\hline Nitrite as $\mathrm{N}$ & $<0.1$ & $<0.1$ & $<3$ & $\mathrm{mg} / \mathrm{L}$ & $\mathrm{A}$ & Excellent \\
\hline Fluoride as F (mg/L) & $<0.1$ & $<0.07$ & 1.5 & $\mathrm{mg} / \mathrm{L}$ & $\mathrm{A}$ & Excellent \\
\hline Iron as $\mathrm{Fe}(\mathrm{mg} / \mathrm{L})$ & 0.01 & $<200$ & $<0.3$ & $\mathrm{mg} / \mathrm{L}$ & $\mathrm{A}$ & Excellent \\
\hline $\begin{array}{l}\text { Calcium as } \mathrm{CaCO}_{3} \\
(\mathrm{mg} / \mathrm{L})\end{array}$ & $<3$ & $<80$ & 200 & $\mathrm{mg} / \mathrm{L}$ & A & Excellent \\
\hline
\end{tabular}

${ }^{a}$ Occurs in drinking water at concentrations well below those of health concerns (WHO 2009) 


\section{Alternative Food Sources under a Changing Climate: Mushrooms}

Though Namibia is an arid country, with very limited terrestrial productivity, there has been a growing interest on mushrooms (edible macrofungi) as an alternative high-value food under the changing climatic environment. Edible macrofungi are highly nutritious with numerous therapeutic benefits as they are rich in proteins, minerals, and vitamins such as B, C, and D (Reeta and Dev 2019). In Namibia, foraging for edible macrofungi is done seasonally just like elsewhere in sub-Saharan Africa (Wahab et al. 2019). Edible macrofungi are mostly foraged for personal consumption but some individuals sell them for a small price, pointing to their potential economic value. Interestingly, those who sell them are unwilling to profit from their sale as they believe that macrofungi are God's given gift (Mshigeni 2001).

Just like other wild crops in Namibia, the availability of macrofungi is influenced by rainfall, with too little or too much having a negative effect on their distribution and abundance. Ethno-mycological studies have reported that Namibian people are aware of the link between the appearance of macrofungi with rainfall, since they refer to the macrofungi as products of a "lightning bird," because they appear after thunderstorms (Trappe et al. 2010). Of recent, wild edible macrofungi are diminishing with unpredictable rainfall events. The unusually heavy rains within a short period, followed by extended drought periods, is reducing the natural growing season of mushrooms. There is therefore a need to shift from the traditional way of exploiting this resource under a changing climate by focusing on cultivation technology. Mushroom cultivation has potential to contribute to diversification of traditional farming in Namibia. Despite the global trend in domestication and cultivation of macrofungi, the focus in Namibia to date has been on the cultivation of the exotic oyster mushrooms (Hausiku and Mupambwa 2018). Even with the oyster mushroom, their cultivation is still on a subsistence scale, partly due to shortages of suitable substrate. As for the indigenous macrofungi, a limited number of research has been done on characterizing their chemical properties and their domestication studies are still in infancy stage if there are any.

\section{Climate Change Implications on Cultivation of Macrofungi in Namibia}

Since macrofungi thrive underground or within substrate during their vegetative stage, their direct response to climate change is challenging to characterize. Consequentially, the timing of their fruit body production is used to study their phenological response to climate change (Bidartondo et al. 2018). Sato et al. (2012) defined phenology as the seasonal timing of life-history events of organisms (in this case, macrofungi). For the Namibian macrofungi, the only documented phenological response to climate change is that of the Kalaharituber, also known as Kalahari truffle (Mshigeni 2001; Leistner 1967) showing a later and shorter fruiting period. This observation is in agreement with long-term datasets documented elsewhere showing that the lengths of the macrofungi-producing season and their timing have 
changed relative to the changes in temperature and rainfall, as have their diversity and range (Bidartondo et al. 2018). It can therefore be deduced that the rising temperature and reduction in precipitation observed in Namibia over the years is having similar effects on macrofungi productivity in Namibia. Studies carried out in the laboratory confirm that temperature and moisture availability affect both the vegetative and fruiting stage of macrofungi. Mycelial growth has been reported to increase with temperature until an optimum temperature is reached, thereafter, the growth decreases (Fletcher 2019). Similar response has been observed in the presence of moisture, whereby insufficient or excessive moisture limits fungal growth. According to Wahab et al. (2019), the average optimal temperature and humidity for mushroom fruiting is around $20^{\circ} \mathrm{C}$ and $80 \%$, respectively.

\section{Current and Future Research on Mushrooms in Namibia}

The projected further increase in temperature and sporadic rainfall patterns coupled with extreme weather events are likely to threaten the already dwindling macrofungal resources of socioeconomic value in Namibia. A few studies have been documented on Namibian macrofungi as summarized in Table 2, and a lot more need to be done in terms of research.

From Table 2, it is obvious that Namibian macrofungi are understudied. All the documented studies on the edible macrofungi (Termitomyces and Kalaharituber species) were done on specimens that were bought from the market. Further studies are needed to address the distribution, ecology, phylogeny, pharmacology, phenology, chemical characterization, and domestication trials.

More studies are documented on nonedible macrofungi (Trametes, Pycnoporu, and Ganoderma species) compared to the edible ones. These studies addressed the phylogeny, indigenous knowledge, and the utilization of these fungi. Further studies are needed to zoom into the biochemical properties of the fungi to isolate and quantify the bioactive compounds responsible for their therapeutic effects reported by the respondents during these studies. Phenological studies would give an idea on the effect of climate change on the different species. Domestication trials would facilitate intensification of research on the fungi as field studies tend to be timeconsuming and expensive.

Namibian mycologists are thus urged to make an effort to domesticate indigenous macrofungal species, especially the edible ones that have largely been neglected by science. Domestication and cultivation will ensure that availability of this resource is not dictated by precipitation or climate. It has been demonstrated by research that cultivation of macrofungi depends on agro-industrial material (e.g., cereal straws, wood chips, etc.) for substrate, and these materials are usually rain fed implying that drought effects on substrate material will trickle down to mushroom productivity. Recent research has been exploring the potential of using marine biomass as a source of organic material to be used as mushroom substrate. In a study by Hausiku and Mupambwa (2018), beach-casted seaweed was used to supplement rice straw in order to fruit oyster mushrooms. The incorporation of seaweed into substrate did not 
Table 2 A summary of studies that have been done on indigenous macrofungi in Namibia

\begin{tabular}{|c|c|c|}
\hline $\begin{array}{l}\text { Macrofungal } \\
\text { species }\end{array}$ & Type of study & Guide for future studies \\
\hline \multirow{5}{*}{$\begin{array}{l}\text { Termitomyces } \\
\text { schimperi and } \\
\text { Kalaharituber } \\
\text { pfeilii }\end{array}$} & $\begin{array}{l}\text { Antimalarial properties of } \\
\text { Termitomyces schimperi and } \\
\text { Kalaharituber pfeilii }\end{array}$ & \multirow{5}{*}{$\begin{array}{l}\text { Distribution, ecology, phylogeny, } \\
\text { pharmacology, phenology, chemical } \\
\text { characterization, antimicrobial } \\
\text { activities, domestication trials. }\end{array}$} \\
\hline & $\begin{array}{l}\text { Characterization of } \\
\text { polysaccharides isolated from } \\
\text { Termitomyces schimperi and } \\
\text { Kalaharituber pfeilii }\end{array}$ & \\
\hline & $\begin{array}{l}\text { Characterization of laccase } \\
\text { enzymes from Termitomyces } \\
\text { schimperi and Kalaharituber pfeilii }\end{array}$ & \\
\hline & $\begin{array}{l}\text { Antiplasmodial activity of Terfezia } \\
\text { pfeilii }\end{array}$ & \\
\hline & $\begin{array}{l}\text { Morphological characterization of } \\
\text { Termitomyces schimperi from } \\
\text { herbarium specimens }\end{array}$ & \\
\hline $\begin{array}{l}\text { General } \\
\text { macrofungi }\end{array}$ & Survey of Namibian macrofungi & $\begin{array}{l}\text { Spatial and temporal distribution } \\
\text { and habitats of the different species, } \\
\text { phylogeny, phenology over time }\end{array}$ \\
\hline \multirow[t]{2}{*}{$\begin{array}{l}\text { Trametes and } \\
\text { Pycnoporus }\end{array}$} & $\begin{array}{l}\text { Phylogeny of Trametes and } \\
\text { Pycnoporus using ITS }\end{array}$ & \multirow{2}{*}{$\begin{array}{l}\text { Biochemical characterization, } \\
\text { phenology, } \\
\text { domestication trials }\end{array}$} \\
\hline & $\begin{array}{l}\text { Ethnomycology of indigenous } \\
\text { Trametes species }\end{array}$ & \\
\hline \multirow[t]{8}{*}{$\begin{array}{l}\text { Ganoderma } \\
\text { lucidum }\end{array}$} & $\begin{array}{l}\text { Antimalarial properties of } \\
\text { Ganoderma lucidum }\end{array}$ & \multirow{8}{*}{$\begin{array}{l}\text { Distribution of the fungus over time. } \\
\text { Characterization and quantification } \\
\text { of bioactive compounds }\end{array}$} \\
\hline & $\begin{array}{l}\text { Minerals and trace elements in } \\
\text { Ganoderma lucidum }\end{array}$ & \\
\hline & $\begin{array}{l}\text { Evaluation of substrate for the } \\
\text { production of Ganoderma lucidum }\end{array}$ & \\
\hline & $\begin{array}{l}\text { Antimicrobial screening of crude } \\
\text { extracts from Ganoderma lucidum }\end{array}$ & \\
\hline & $\begin{array}{l}\text { Antiplasmodial activity } \\
\text { Ganoderma lucidum }\end{array}$ & \\
\hline & $\begin{array}{l}\text { Traditional medicinal uses and } \\
\text { natural hosts }\end{array}$ & \\
\hline & Genetic diversity of Ganoderma & \\
\hline & $\begin{array}{l}\text { Distribution, genetic diversity, and } \\
\text { uses of Ganoderma }\end{array}$ & \\
\hline
\end{tabular}

only add value to the beach-casted seaweed but enhanced the nutritional benefits of the mushrooms.

Identification, collection, and domestication of native wild mushrooms is another aspect of fungal science that have been overlooked. Such studies are imperative in facilitating taxonomical and ethno-mycological studies of indigenous macrofungi. Furthermore, documentation on the traditional use of Namibian macrofungi and assessment of their local and international markets would expedite their industrial 
relevance (Shahtahmasebi et al. 2018). Besides domestication, value addition of macrofungi with socioeconomic importance such as the Termitomyces and the Kalaharituber is important. Food technologists need to find ways to increase the shelf life of this highly perishable commodity by creating new products that are different from the traditional forms in which macrofungi are consumed in order to contribute to the country's GDP.

\section{Organic Agriculture and Its Potential Under a Changing Climate}

With Namibia being an arid country, terrestrial biomass production is very limited, which has consequently resulted in very poor quality soils in most parts of the country. The soils in Namibia therefore lack fertility as they are mostly sandy and very old (Zimmermann et al. 2017). Under natural conditions, terrestrial biomass results in the generation of huge quantities of organic matter which is deposited into the soil, where it becomes part of soil organic carbon. Soil organic carbon or soil organic matter plays a critical role in soil quality, with the following functions:

- The non-humic substances produced during the decomposition of organic matter, e.g., polysaccharides encourage granulation - the binding of soil particles into aggregates. These aggregates help to maintain a loose, open, granular condition. This improves the aeration and water infiltration capacity of the soil.

- Organic matter can hold up to 20 times its weight in water. Its presence in the soil, therefore, improves the soils' water holding capacity. This is especially important in sandy soils.

- Organic matter (humus colloids) has a high cation exchange capacity (2-30 times as great (per $\mathrm{kg}$ ) as that of various types of clay minerals). It therefore adsorbs and stores plant nutrients $\left(\mathrm{K}^{+} \mathrm{Ca}^{2+}, \mathrm{Mg}^{2+}\right.$, etc. $)$ and thus improves the fertility of soil.

- Humus colloids form stable complexes with $\mathrm{Cn}^{2+}, \mathrm{Zn}^{2+}, \mathrm{Mn}^{2+}$, and other polyvalent cations. This may enhance the availability of micronutrients to higher plants.

- Decomposition of soil organic matter release $\mathrm{NH}_{4}+, \mathrm{NO}_{3}{ }^{-}, \mathrm{PO}_{4}{ }^{3-}$, and thus serves as a source of nutrients to plants.

- Organic matter serves as a source of energy for both macro- and microfaunal organisms. These organisms in turn play important roles in soils, e.g., earthworms which are important agents for good soil structure, bacteria responsible for mineralization processes, etc.

- Humic acids also attack soil minerals and accelerate their decomposition, thereby releasing essential elements as exchangeable cations.

- In very acid soils, organic matter alleviates aluminum toxicity by binding $\mathrm{Al}^{3+}$ ions in nontoxic complexes

Soils with low organic matter are therefore prone to degradation and this is the major cause of reduced agricultural productivity and food security in countries 
like Namibia. With poor quality soils mainly due to low organic matter content, much of Namibian agriculture is more at risk of the effects of climate change such as reduced rainfall, flooding, increased environmental temperature among others, which will require more resilient soils.

From the Namibian perspective, a shift from the conventional agriculture that replicates the green revolution technologies such as intensive use of fertilizers, pesticides, and machinery is required, towards more organic-based agriculture systems is important. The current conventional agriculture practices have not focused on soil fertility but rather only on the crop fertility, which has actually seen crops yields in most parts of the country decreasing in the face of climate change. Organic agriculture practices are among some of the systems that are being promoted among others like ecological agriculture, sustainable intensification, and conservation agriculture, as these systems focus more on feeding the soil making it more resilient under climate change (Mupambwa et al. 2020). Organic agriculture is a more holistic production system which promotes agroecosystem health approach which promotes the use of management practices in preference to the use of off-farm inputs (FAO/WHO 1999).

Zimmermann et al. (2017) highlighted that Namibia has important resources that can be used in organic soil fertility which include animal manures, fertilizer trees harvestable from nature; marine resources such as seaweeds; bird guano and animal processing waste such as blood, bones, and fish waste. Technologies like composting and vermicomposting can be used in improving the fertilizer value of these waste materials, which can then be used as soil amendments. Current research being undertaken in Namibia on developing organic nutrient-rich fertilizers includes the optimization of the biodegradation and nutrient release during vermicomposting of various household waste, marine biomass, and farm waste materials. Such research is important in standardizing the production processes of organic fertilizers, thus allowing for greater uptake of these fertilizers among smallholder farmers. The lack of nutrient predictability and standardization of organic fertilizer production results in even those that are commercially available on the market being sold without any labeling that indicates nutritional composition as is mandatory for inorganic fertilizers. The specification of compost quality is more important as it enables compost users to more effectively manage their agroecosystems (Mupambwa and Mnkeni 2018).

Several researchers are undertaking research that is linked to organic agriculture in Namibia and these are summarized in Table 3 below.

Research on uses of organic soil fertility conditioners is currently happening in Namibia, though not much of it is not directly linked to mitigating the effects of climate change. There is a need to marry the two, so that such research can directly fit into the National Climate Change Strategy and Action Plan for 2013-2020 of Namibia. It is also important to note that there is very limited research available for Namibia on evaluating the potential of organic agriculture in improving soil quality, though several reviews are available on this subject. 
Table 3 A summary of some of the studies that have focused on aspects relating to organic agriculture in Namibia

\begin{tabular}{|c|c|c|c|c|}
\hline $\begin{array}{l}\text { Study details and } \\
\text { location }\end{array}$ & Key results & $\begin{array}{l}\text { Climate } \\
\text { mitigation effects }\end{array}$ & Future research & Reference \\
\hline $\begin{array}{l}\text { The study } \\
\text { evaluated the } \\
\text { used of three rates } \\
\text { of cattle manure } \\
\text { at } 0,31 \text {, and } \\
62 \mathrm{Mg} / \text { ha within } \\
\text { three cropping } \\
\text { systems, i.e., } \\
\text { pearl millet } \\
\text { (Pennisetum } \\
\text { glaucum L.) } \\
\text { mono-cropping; } \\
\text { cowpea (Vigna } \\
\text { unguiculata } \mathrm{L} .) \\
\text { mono-cropping; } \\
\text { and pearl millet- } \\
\text { cowpea } \\
\text { intercropping. } \\
\text { The soil was a } \\
\text { sandy soil from } \\
\text { Ogongo, Omusati } \\
\text { Region with a pH } \\
\text { ( } \mathrm{H}_{2} \mathrm{O} \text { ) = } 7.0 \text { and } \\
2.8 \text { g total } \mathrm{C} / \mathrm{kg} \\
\text { soil. }\end{array}$ & $\begin{array}{l}\text { Application of } \\
\text { manure increased } \\
\text { soil organic } \\
\text { carbon by } 1.3 \text { and } \\
1.7 \text { times under } \\
\text { the } 31 \text { and } 62 \mathrm{Mg} / \\
\text { ha, respectively. } \\
\text { Furthermore, } \\
\text { manure } \\
\text { application } \\
\text { significantly } \\
\text { increased the } \\
\text { concentration of } \\
\text { most } \\
\text { macronutrients } \\
\text { compared to the } \\
\text { control. However, } \\
\text { cropping system } \\
\text { did not result in } \\
\text { differences in } \\
\text { most of these } \\
\text { parameters. The } \\
\text { study also } \\
\text { observed that } \\
\text { there was } \\
\text { optimization on } \\
\text { the benefits of } \\
\text { manure addition } \\
\text { at the lower rate } \\
\text { of } 31 \mathrm{Mg} / \text { ha. }\end{array}$ & $\begin{array}{l}\text { Soil organic } \\
\text { carbon (SOC) can } \\
\text { be significantly } \\
\text { increased by } \\
\text { addition of cow } \\
\text { manure, which } \\
\text { has the potential } \\
\text { to improve soil } \\
\text { quality in sandy } \\
\text { degraded soils. } \\
\text { Higher SOC } \\
\text { increases the } \\
\text { resilience of soils } \\
\text { and improves } \\
\text { water and nutrient } \\
\text { retention, which } \\
\text { has potential to } \\
\text { increase yields } \\
\text { under } \\
\text { smallholder } \\
\text { farmers. }\end{array}$ & $\begin{array}{l}\text { There is need to } \\
\text { improve the } \\
\text { quality of the } \\
\text { manure applied } \\
\text { through processes } \\
\text { such as } \\
\text { composting and } \\
\text { vermicomposting } \\
\text { and evaluating } \\
\text { these improved } \\
\text { organic nutrient } \\
\text { sources. } \\
\text { There is need for } \\
\text { long-term studies } \\
\text { evaluating the } \\
\text { influence of } \\
\text { animal manures } \\
\text { on soil quality, } \\
\text { which considers } \\
\text { changes soil } \\
\text { chemical, } \\
\text { biological, and } \\
\text { physical } \\
\text { properties. } \\
\text { Optimization of } \\
\text { long-term } \\
\text { application rates } \\
\text { of animal } \\
\text { manures which is } \\
\text { informed by crop } \\
\text { requirements is } \\
\text { essential. }\end{array}$ & $\begin{array}{l}\text { Watanabe } \\
\text { et al. } \\
(2019)\end{array}$ \\
\hline $\begin{array}{l}\text { The study } \\
\text { evaluated an } \\
\text { organic } \\
\text { hydroponic } \\
\text { nutrient solution } \\
\text { prepared from } \\
\text { goat manure } \\
\text { processed } \\
\text { through } \\
\text { composting goat } \\
\text { manure for } \\
6 \text { months and } \\
\text { then extracting } \\
\text { the nutrients from } \\
\text { the compost by a } \\
\text { process of } \\
\text { leaching for } \\
7 \text { days. The study }\end{array}$ & $\begin{array}{l}\text { The use of } \\
\text { organic } \\
\text { hydroponic } \\
\text { solution did not } \\
\text { result in } \\
\text { significant } \\
\text { differences in } \\
\text { vegetative plant } \\
\text { growth with the } \\
\text { commercial } \\
\text { hydroponic } \\
\text { fertilizer, which } \\
\text { were all different } \\
\text { from the control } \\
\text { with the lowest } \\
\text { vegetative growth } \\
\text { In terms of yield } \\
\text { parameters, }\end{array}$ & $\begin{array}{l}\text { Important } \\
\text { vegetable crops } \\
\text { like tomatoes can } \\
\text { be grown in under } \\
\text { hydroponic } \\
\text { systems that are } \\
\text { fertilized using } \\
\text { organic nutrient } \\
\text { sources. } \\
\text { The use of } \\
\text { hydroponics } \\
\text { which are cheap } \\
\text { allows for the } \\
\text { production of } \\
\text { crops under the } \\
\text { smallholder } \\
\text { farmers with } \\
\text { limited water use }\end{array}$ & $\begin{array}{l}\text { Evaluating more } \\
\text { nutrient-rich } \\
\text { compost types } \\
\text { called } \\
\text { vermicomposts as } \\
\text { hydroponic } \\
\text { nutrient sources. } \\
\text { Evaluating the } \\
\text { effectiveness of } \\
\text { using } \\
\text { amendments like } \\
\text { rock phosphate, } \\
\text { fly ash, and } \\
\text { biochar in } \\
\text { improving the } \\
\text { fertilizer value of } \\
\text { these organic } \\
\text { nutrient sources. }\end{array}$ & $\begin{array}{l}\text { Mowa } \\
\text { (2015) } \\
\text { and } \\
\text { Mowa } \\
\text { et al. } \\
\text { (2017) }\end{array}$ \\
\hline
\end{tabular}


Table 3 (continued)

\begin{tabular}{|c|c|c|c|c|}
\hline $\begin{array}{l}\text { Study details and } \\
\text { location }\end{array}$ & Key results & $\begin{array}{l}\text { Climate } \\
\text { mitigation effects }\end{array}$ & Future research & Reference \\
\hline $\begin{array}{l}\text { had three } \\
\text { treatments, i.e., } \\
\text { the organic } \\
\text { hydroponic } \\
\text { fertilizer; a } \\
\text { commercial } \\
\text { hydroponic } \\
\text { fertilizer, and a } \\
\text { control of water } \\
\text { alone. A floating } \\
\text { deep water } \\
\text { culture } \\
\text { hydroponic } \\
\text { system was then } \\
\text { used for growing } \\
\text { tomatoes. The } \\
\text { study was done in } \\
\text { a greenhouse in } \\
\text { Henties Bay } \\
\text { located within the } \\
\text { coast of Namibia. }\end{array}$ & $\begin{array}{l}\text { tomato plants } \\
\text { grown under the } \\
\text { commercial } \\
\text { hydroponic } \\
\text { fertilizer } \\
\text { produced more } \\
\text { than those grown } \\
\text { under manure } \\
\text { nutrient solution } \\
\text { which in turn, } \\
\text { produced more } \\
\text { than the plants } \\
\text { grown under the } \\
\text { control. }\end{array}$ & $\begin{array}{l}\text { and low fertilizer } \\
\text { costs. } \\
\text { Hydroponics are } \\
\text { critical in } \\
\text { increasing food } \\
\text { production under } \\
\text { a changing } \\
\text { climate, where } \\
\text { fresh water will } \\
\text { become scare. }\end{array}$ & & \\
\hline $\begin{array}{l}\text { The study was } \\
\text { undertaken in } \\
\text { Kavango East } \\
\text { Region (Mashare } \\
\text { Irrigation } \\
\text { Training Center - } \\
\text { MITC) and } \\
\text { Zambezi Region } \\
\text { (Liselo Research } \\
\text { Station - LRS). } \\
\text { Two experiments } \\
\text { one with pearl } \\
\text { millet } \\
\text { (Pennisetum } \\
\text { glaucum) and the } \\
\text { other with maize } \\
\text { (Zea mays); } \\
\text { which were } \\
\text { rotated with } \\
\text { different Green } \\
\text { Manure Cover } \\
\text { Crops (GMCC) } \\
\text { to evaluate their } \\
\text { effects on the } \\
\text { productivity } \\
\text { (grain and } \\
\text { biomass yields) } \\
\text { among other } \\
\text { parameters. }\end{array}$ & $\begin{array}{l}\text { The GMCC } \\
\text { lablab resulted in } \\
\text { the highest } \\
\text { biomass yield } \\
\text { with a mean yield } \\
\text { of } 11,500 \mathrm{~kg} / \mathrm{ha} \\
\text { while jack bean } \\
\text { had the lowest } \\
\text { yield of } 1000 \mathrm{~kg} / \\
\text { ha. } \\
\text { Similarly, lablab } \\
\text { in the pearl millet } \\
\text { rotation resulted } \\
\text { in the greatest } \\
\text { grain yield of } 3 \\
\text { tonnes/ha, with } \\
\text { jack bean, } \\
\text { bambara nut, and } \\
\text { common sun } \\
\text { hemp producing } \\
\text { lower grain } \\
\text { yields. } \\
\text { At LRS, the } \\
\text { greatest biomass } \\
\text { yield was } \\
\text { observed in the } \\
\text { velvet bean } \\
\text { treatment with a } \\
\text { mean yield of } \\
5900 \mathrm{~kg} / \mathrm{ha} \text {. }\end{array}$ & $\begin{array}{l}\text { Green manure } \\
\text { cover crops can } \\
\text { significantly } \\
\text { contribute to the } \\
\text { addition of soil } \\
\text { organic matter } \\
\text { thus increasing } \\
\text { the soil organic } \\
\text { carbon of the soil, } \\
\text { which } \\
\text { consequently } \\
\text { improves soil } \\
\text { quality. } \\
\text { The legume green } \\
\text { manure cover } \\
\text { crops can be } \\
\text { effective in fixing } \\
\text { atmospheric N } \\
\text { into the soil, thus } \\
\text { reducing the use } \\
\text { of inorganic } \\
\text { fertilizers. }\end{array}$ & $\begin{array}{l}\text { Monitoring the } \\
\text { long-term } \\
\text { contribution of } \\
\text { the GMCC to } \\
\text { overall soil } \\
\text { quality under } \\
\text { various } \\
\text { combinations. } \\
\text { Evaluating the } \\
\text { potential of } \\
\text { agroforestry tree } \\
\text { species in } \\
\text { agroecology in } \\
\text { Namibia. }\end{array}$ & $\begin{array}{l}\text { Amakali } \\
\text { (2019) }\end{array}$ \\
\hline
\end{tabular}




\section{Conclusions}

The contribution of Namibia and most countries in southern Africa to climate change through the global increase in atmospheric pollutants that are drivers of global warming is very minimal. However, it is apparent that the impacts of this global change in climate due to human-induced activities will influence everyone on earth, with the effects expected to be even more pronounced in already hyperarid countries like Namibia. Namibia has made huge progress at policy level with regards to issues of climate change. However, there is need for more urgent research that directly feeds into the climate change strategy and action plan for Namibia. This research will need to focus on understanding more on the effects of anthropogenic activities on the atmosphere, water, and land activities, in a holistic manner. With the country being hyperarid, research that is currently underway on using clean energy sources like solar, wind, and tidal power for sea water desalination can be critical in abetting the effects on climate change on fresh water availability in Namibia. However, there is need for research on engineering locally adaptable technologies that can take this fresh water from the coast to other places of the country for use in agricultural activities, thus creating green belts in Namibia, capable of improving the country's food self-sufficiency. With Namibia being blessed with a vast marine environment, research on the effects of climate change on this unique marine environment and how it will affect economic activities in this industry will also be critical. Overly, Namibia is making progress on generating research critical in mitigating against climate change, and the future will require more research with a multidisciplinary approach to feed into the country's climate change action plan.

\section{References}

Amakali S (2019) Effects of green manure cover crops on weed population, pearl millet and maize productivity under conservation agriculture in Liselo and Mashare Namibia. MSc thesis, University of Namibia

Anderson P, Currie B, Louw DC, Anderson DM, Fernández-Tejedor M, McMahon T, Rangel I, Ellitson P, Torres O (2004) Feasibility study for cost-effective monitoring in Namibia and Angola with an analysis of the various options for implementation of Shellfish Safety Programs. Final Report. BCLME project EV HAB/02/02a: Development of an Operational Capacity for Monitoring of Harmful Algal Blooms in Countries Bordering the Northern part of the Benguela Current Large Marine Ecosystem Phase 1 -Design

Bidartondo MI, Ellis C, Kauserud H, Kennedy PG, Lilleskov EA, Suz LM, Andrew C (2018) Climate change: fungal responses and effects. In: Willis KJ (ed) State of the world's fungi. Report. Royal Botanic Gardens, Kew, pp 62-69

Branch TA, DeJoseph BM, Ray LJ, Wagner CA (2013) Review - impacts of ocean acidification on marine seafood. Trends Ecol Evol 28(3):178-186

Christelis G, Struckmeier WF (2011) Groundwater in Namibia. In Water

Chung CE, Ramanathan V, Kim D, Podgorny IA (2005) Global anthropogenic aerosol direct forcing derived from satellite and ground-based observations. J Geophys Res 110:D24207. https://doi.org/10.1029/2005JD006356

Compain P (2012) Solar Energy for Water desalination 46(0):220-227. https://doi.org/10.1016/j. proeng.2012.09.468 
COW (2019) Water management plan. City of Windhoek, Windhoek

Darre NC, Toor GS (2018) Desalination of water: a review desalination of water: a review. March. https://doi.org/10.1007/s40726-018-0085-9

Doney SC (2006) The dangers of ocean acidification. Sci Am 294(3):58-65

FAO (2005) Namibia Aquastat Survey. 1-14. http://www.fao.org/nr/water/aquastat/countries regions/NAM/NAM-CP eng.pdf

FAO/WHO (1999) Codex Alimentarius commission approves guidelines for organic food. http://www.fao.org/organicag/oa-faq/oa-faq1/en/. Accessed 23 June 2020

Fletcher IA (2019) Effect of temperature and growth media on mycelium growth of Pleurotus ostreatus and Ganoderma lucidum Strains. Cohesive J Microbiol Infect Dis 2(5). ISSN 25780190. https://doi.org/10.31031/CJMI.2019.02.000549

Formenti P, John Piketh S, Namwoonde A, Klopper D, Burger R, Cazaunau M et al (2018) Three years of measurements of light-absorbing aerosols over coastal Namibia: seasonality, origin, and transport. Atmos Chem Phys 18(23). https://doi.org/10.5194/acp-18-17003-2018

Formenti P, D'Anna B, Flamant C, Mallet M, Piketh SJ, Schepanski K, ... Holben B (2019) The aerosols, radiation and clouds in southern Africa field campaign in Namibia overview, illustrative observations, and way forward. Bull Am Meteorol Soc, 100(7):1277-1298. https://doi.org/ 10.1175/BAMS-D-17-0278.1

Hausiku MK, Mupambwa HA (2018) Seaweed amended rice straw substrate and its influence on health related nutrients, trace elements, growth and yield of edible white elm mushroom (Hypsizygus ulmarius). Int J Agric Biol 20:2763-2769

Heintzenberg J (1985) What can we learn from aerosol measurements at baseline stations? J Atmos Chem 3(1):153-169. https://doi.org/10.1007/BF00049374

Lahnsteiner J, Lempert G (2007) Water management in Windhoek, Namibia. Water Sci Technol 55 (1-2):441-448. https://doi.org/10.2166/wst.2007.022

Leistner OA (1967) The plant ecology of the southern Kalahari, Republic of South Africa. Bot Res Inst Bot Surv Mem 38:1-172

Lubinda M (2015) Factsheet on climate change: the definition, causes, effects and responses in Namibia. https://www.thinknamibia.org.na/files/learn-and-engage/TlaQWEcwS5WDIWme. pdf. Accessed 22 June 2020

Mapaure I (2011) Climate change in Namibia: projected trends and effects. In: Ruppel OC, RuppelSchlichting K (eds) Environmental Law and Policy in Namibia. Hans Seidel Foundation, Windhoek, pp 291-309

MET (Ministry of Environment and Tourism) (2011) National policy on climate change for Namibia. Government of the Republic of Namibia, Windhoek

Michou T (2017) Water and greenhouse gases: the desalination challenge

Ministry of Agriculture Water and Forestry (MAWF) (2015) Namibia agriculture policy. Ministry of Agriculture Water and Forestry, Windhoek

Mowa E (2015) Organic manure for vegetable production under hydroponic conditions in arid Namibia. Int Sci Technol J Namibia 5:3-12

Mowa E, Akundabweni L, Chimwamurombe P, Oku E, Mupambwa HA (2017) The influence of organic manure formulated from goat manure on growth and yield of tomato (Lycopersicum esculentum). Afr J Agric Res 12(41):3061-3067. https://doi.org/10.5897/AJAR2017.12657

Mshigeni KE (2001) The cost of scientific and technological ignorance with special reference to Africa's rich biodiversity. University of Namibia, Windhoek. https://doi.org/10.4314/dai.v13i3. 15605

Mupambwa HA, Mnkeni PNS (2018) Optimizing the vermicomposting of organic waste amended with inorganic materials for production of nutrient-rich organic fertilizers: a review. Environ Sci Pollut R 25:10577-10595

Mupambwa HA, Ravindran B, Dube E, Lukashe NS, Katakula AAN, Mnkeni PNS (2020) Some perspectives on Vermicompost utilization in organic agriculture. In: Bhat SA, Vig AP, Li F, Ravindran B (eds) Earthworm assisted remediation of effluents and wastes. Springer, Japan, pp 299-331 
Norton JM (2011) Ocean acidification: cause, effect, and potential mitigation approaches. A Journal of Academic Writing, Hohonu, p 9

OLRAC (2009) Specialist study: marine ecology impact assessment. Environmental impact assessment for the proposed expansion of the container terminal at the port of Walvis Bay. Prepared by OLRAC (Ocean and land resource assessment consultants) for CSIR Stellenbosch

Petrick W, Müller S (2019) Erongo desalination plant environmental management plan, Swakopmund

Pollard RT, Salter I, Sanders RJ, Lucas MI, Moore MC, Mills RA, Statham PJ, Allen JT, Baker AR, Bakker DCE, Charette MA, Fielding S, Fones GR, French M, Hickman AE, Holland RJ, Hughes Aj, Jickells TD, Lampitt RS, Morris PJ, Nedelec FH, Nielsdottir M, Planquette H, Popova EE, Poulton AJ, Read JF, Seevave S, Smith T, Stinchcombe M, Taylor S, Thomalla S, Venables HJ, Williamson R, Zubkov MV (2009) Southern Ocean deep-water carbon export enhanced by natural iron fertilization. Nature 457:577-580

Pryor AM, Blanco B, Galtes J (2009) Desalination and energy efficiency for a uranium mine in Namibia. Ground Water:1-16

Ramadan E (2015) Sustainable water resources management in arid environment: the case of Arabian Gulf. Int J Waste Resour 05(03):3-6. https://doi.org/10.4172/2252-5211.1000179

Reeta M, Dev MY (2019) Performance of oyster mushroom through use of different agro Byproducts. J Community Mobilization Sustain Dev 14(1):174-178

Reid H, Sahlen L, Stage J, Macgregor J (2008) Climate change impacts on Namibia's natural resources and economy. Clim Pol 8:452-466

Sato H, Morimoto S, Hattori T (2012) A thirty-year survey reveals that ecosystem function of fungi predicts phenology of mushroom fruiting. PloS one 7(11):e49777. https://doi.org/10.1371/ journal.pone. 0049777

Shahtahmasebi SH, Pourianfar HR, Mahdizadeh V, Shahzadeh Fazeli SA, Amoozegar MA, Nasr SH, Zabihi SS, Rezaeian SH, Malekzadeh KH, Janpoor J (2018) A preliminary study on domestication of wild-growing medicinal mushrooms collected from Northern Iran. Journal of Fungal Biology 8(6):606-623

Sweet J, Burke A (2006) Country pasture/forage resource profiles Namibia. In: FAO. Namibia climate-smart agriculture program. Food and Agriculture Organization of the United Nations (FAO), Windhoek, pp 2015-2025

Takeo H, Shoko K, Koichi S, Yuhi S, Yuko O, Shigeki W, Taiki A, Shun H, Takashi M, Masao I, Shu S, Daisuke S, Hiroko E, Tsuyoshi N, Isao I (2012) Effect of ocean acidification on coastal phytoplankton composition and accompanying organic nitrogen production. J Oceanogr 68:183-194

Tal A (2018) Addressing desalination's carbon footprint: the Israeli experience. Water (Switzerland) 10(2). https://doi.org/10.3390/w10020197

Trappe JM, Kovács GM, Claridge AW (2010) Validation of the new combination Mattirolomyces austroafricanus. Mycol Progr 9:145. https://doi.org/10.1007/s11557-009-0631-3

Villafaňe VE, Valiňas MS, Cabrerizo MJ, Helbling EW (2015) Physio-ecological responses of Patagonian coastal marine phytoplankton in a scenario of global change: role of acidification, nutrients and solar UVR. J Mar Chem 177:-411

Wahab HA, Manap MZIA, Ismail AE, Pauline O, Ismon M, Zainulabidin MH, Mat Noor F, Mohamad Z (2019) Investigation of temperature and humidity control system for mushroom house. Int J Integrated Eng 11(6):27-37

Waldron HN, Monteiro PMS, Swart NC (2009) Carbon export and sequestration in the southern Benguela upwelling system: lower and upper estimates. Ocean Sci 5:711-718

Watanabe Y, Itanna F, Izumi Y, Awala SK, Fujioka Y, Tsuchiya K, Iijima M (2019) Cattle manure and intercropping effects on soil properties and growth and yield of pearl millet and cowpea in Namibia. J Crop Improv 33(3):395-409

Wei L, Wang Q, Wu H, Ji C, Zhao J (2014) Proteomic and Metabolomic responses of pacific oyster Crassostrea gigas to elevate pCO2 exposure. J Proteome 112:83-94

WHO (2009) Potassium in drinking-water. Background document for preparation of WHO. Guidelines for drinking-water quality. Geneva: World Health Organization (WHO/HSE//09.01/7) 
Wilhelm M (2012) The impact of climate change in Namibia- a case study of Omusati region. Ounongo Repository:1-101. http://ir.nust.na/handle/10628/381

Zimmermann I, Matzopoulos R, Kwaambwa HM (2017) Options to improve soil fertility with national resources. Namibian J Environ 1(B):7-15

Open Access This chapter is licensed under the terms of the Creative Commons Attribution 4.0 International License (http://creativecommons.org/licenses/by/4.0/), which permits use, sharing, adaptation, distribution and reproduction in any medium or format, as long as you give appropriate credit to the original author(s) and the source, provide a link to the Creative Commons license and indicate if changes were made.

The images or other third party material in this chapter are included in the chapter's Creative Commons license, unless indicated otherwise in a credit line to the material. If material is not included in the chapter's Creative Commons license and your intended use is not permitted by statutory regulation or exceeds the permitted use, you will need to obtain permission directly from the copyright holder.

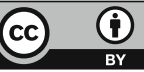

